\title{
Novos quilombos Metamorfoses étnicas e a dificil memória da escravidão no Brasil
}

\author{
Hebe Maria Mattos
}

O’DWYER, Eliane Cantarino (org.). Quilombos. Identidade étnica e territorialidade. Rio de Janeiro: Editora FGV, 2002, 268 p.

ALMEIDA, Alfredo Wagner Berno de (org.). Terras de Preto no Maranhão: Quebrando o mito do isolamento. São Luís: Centro de Cultura Negra do Maranhão (CCN-MA) e Sociedade Maranhense de Direitos Humanos (SMDH), 2002, 272 p.

Cerca de duas centenas de indivíduos, em sua maioria negros, todos aparentados da matriarca Maria da Cruz, vivem em Sacutiaba e Riacho de Sacutiaba no oeste bahiano. Segundo a memória da comunidade, seus antepassados chegaram na área a cerca de 200 anos, e lá viveram sem qualquer tipo de restrição dos proprietários nominais das terras até as mesmas serem adquiridas pelos atuais proprietários, em 1973. Desde então, a comunidade começou a ter seus direitos tradicionais de uso do solo ameaçados, mobilizando-se, com a ajuda de diversos aliados (políticos locais, advogados), contra as ameaças com que passaram a conviver. Em 1995, enviaram representação à Fundação Palmares solicitando a regularização de seu território, consoante os termos do art. 68 do Ato das Disposiçôes Constitucionais Transitórias da Constituição Federal de 1988 ("Aos remanescentes das comunidades dos quilombos que estejam ocupando suas terras é reconhecida a propriedade definitiva, devendo o Estado emitir-lhes os títulos respectivos"). Os moradores de Sacutiaba não têm qualquer memória familiar de escravos fugidos entre seus antepassados. Todos se reconhecem majoritariamente negros, apesar de "um ou outro caboclo". Sabem, também, da avó de Maria da Cruz, "nagô legítima", bem como afirmam que a comunidade era do "tempo do nego véio". "Não sei se 
meu pai foi escravo" (diz Maria da Cruz) "mas deve ter sido porque é herança de nego. Podem ter libertado, mas foi". Afirma-se assim uma identidade étnica referenciada à origem na escravidão e em um campesinato precocemente formado por pretos forros na região. A menção a acampamentos de escravos fugidos nas proximidades da área não está ausente das fontes históricas. Nesse sentido, "a identidade histórica de remanescente de quilombo emerge como resposta atual diante de uma situação de conflito e confronto". Em torno deste eixo, estrutura-se o laudo antropológico de identificação como remanescente de quilombo da comunidade negra rural de Sacutiaba e Riacho de Sacutiaba (produzido para fins de aplicação do artigo 68 do Ato das Disposições Constitucionais Transitórias da Constituição Brasileira de 1988) e agora publicado, entre outros laudos, no livro Quilombos, identidade étnica e territorialidade, editado pela FGV e a Associação Brasileira de Antropologia - ABA (organizado por Eliane Cantarino O’Dwyer).

Estes territórios étnicos já vinham sendo mapeados por antropólogos e pelos movimentos negros desde a década de 1970, chamados comunidades negras rurais por estes e de terras de pretos, por seus próprios integrantes. O relatório do Projeto Vida de Negro, sobre as terras de pretos no Maranhão, coordenado pelo antropólogo Alfredo Wagner, foi escrito em 1988 e 1989 e está sendo finalmente publicado. Na mesma época, aprovava-se na nova Constituição Federal, o artigo 68 do Ato das Disposições Transitórias (ADCT).

Apesar de algumas limitações formais, próprias de um relatório de pesquisa, o texto de Terras de Preto no Maranhão lançou as bases de dois dos pilares a partir dos quais iria se desenvolver a discussão sobre o reconhecimento dos grupos remanescentes de quilombos referidos na Constituição e do papel dos laudos antropológicos neste processo: 1) a definição das terras de pretos, a partir da auto-identificação étnica dos integrantes e do uso comum das terras; 2) o levantamento de documentação histórica sobre a existência de quilombos, especialmente no século XIX, próximos às áreas nas quais se situam as comunidades.

A aplicação prática do artigo constitucional causou inicialmente profundas controvérsias entre antropólogos e historiadores. Como não existe no Brasil qualquer fenômeno histórico da dimensão dos Saramaka do Suriname ou dos remanescentes 
de quilombo da Jamaica, com seus territórios históricos definidos por tratados coloniais, como regulamentar e definir os grupos rurais que poderiam ser enquadrados como remanescentes dos quilombos? A expressão remanescentes dos quilombos, tomada em sentido estrito, como continuidade histórica de comunidades de ex-escravos fugidos, seria aplicável apenas a uns poucos grupos, em especial na região Amazônica, no norte do país. Richard Price criticou fortemente alguns dos primeiros laudos antropológicos de identificação de áreas remanescentes de quilombo, redigidos por antropólogos brasileiros, por caracterizarem de forma superficial e imprecisa determinados grupos contemporâneos de camponeses negros como descendentes de antigas comunidades quilombolas. ${ }^{1}$

Em resposta a este tipo de objeção, a Associação Brasileira de Antropologia caminhou para uma proposta de definição operacional do termo remanescentes das comunidades dos quilombos do artigo constitucional, considerando os processos de emergência étnica em curso. $\mathrm{O}$ grupo de trabalho sobre Terras de Quilombos da ABA (Associação Brasileira de Antropologia) considerou que as expressóes quilombo e rema- nescente de quilombo sofreram um verdadeiro processo de ressemantização no Brasil, com base na mobilização das próprias comunidades negras rurais que passaram a assim se autodenominar. É a construção prática desta orientação que pode ser acompanhada nos dois livros aqui considerados.

A introdução de Eliane Cantarino O'Dwyer para o livro da ABA reflete sobre este processo ("os quilombos e a prática profissional dos antropólogos”). Apóia-se teoricamente em Fredrik Barth para afirmar a condição de remanescente de quilombo como uma identidade construída, com base em um território e em uma origem comum, a partir da situação presente das comunidades. Apesar da ênfase do livro nas situações presentes, própria às abordagens antropológicas, o capítulo de Alfredo Wagner, ainda com base na experiência com as terras de preto do Maranhão, procura fazer face à controvérsia entre antropólogos e historiadores. Nesta empreita$\mathrm{da}$, atribui muitas vezes aos historiadores paradigmas e perspectivas bastante estereotipadas. Apesar disto, o autor acaba por corroborar muito do que a pesquisa histórica mais recente tem revelado sobre os últimos anos da sociedade escravis- 
ta no Brasil. Seu argumento sobre um certo "acamponesamento" de determinados setores da sociedade escravista, ocorrido nas últimas décadas do século passado e capaz de propiciar o desenvolvimento de situações de autonomia próximas do ideal de uma comunidade quilombola, poderia ser muitíssimo reforçado se incorporasse parte da produção recente sobre a história social da abolição no Brasil. ${ }^{2}$ A legislação que reconhece o direito dos remanescentes de quilombos está, de fato, fazendo emergir territórios negros organizados a partir da experiência dos últimos anos da escravidão. Um campesinato negro formado por escravos forros e seus descendentes, movimentos endêmicos de fugas de cativos e comunidades escravas enraizadas, com uma economia autônoma altamente desenvolvida, faziam parte daquele contexto.

Os interessantíssimos casos analisados no livro da ABA (Sacutiaba, no oeste bahiano, analisada por Sheila Brasileiro e José Augusto Sampaio; Conceição das Crioulas, em Pernambuco, em laudo de Vânia Rocha Souza; o Quilombo do
Laudêncio, no Espírito Santo, em texto de Oswaldo de Oliveira; Jamari dos Pretos, no Maranhão, por Eliane Cantarino e José Paulo de Carvalho; Furnas do Dionísio, no Mato Grosso, em belo ensaio de Maria de Lourdes Bandeira e Triana Dantas; concluindo com os Quilombos do Trombetas, também de Eliane Cantarino O’Dwyer) nos descortinam, de forma surpreendente, o cenário de um campo negro, tornado visível pela mobilização produzida pela aprovação do artigo constitucional, fortemente marcado por uma etnicidade construída a partir da memória dos últimos anos da escravidão no Brasil.

\section{Notas}

${ }^{1}$ Cf. Richard Price. Reinventando a História dos Quilombos. Rasuras e Confabulações. In: Afro-Ásia, 23 (1999), 239-265.

${ }^{2}$ Cf., entre outros, Gomes, Flávio dos Santos. História de Quilombolas. Rio de Janeiro, Arquivo Nacional, 1995; Machado, Maria Helena. O Plano e o Pânico. Rio de Janeiro: EDUFRJ, 1994; Mattos, Hebe Maria. Das Cores do Silêncio. Rio de Janeiro: Arquivo Nacional/ Ed. Nova Fronteira, $1995 / 1997$. 